\title{
Classroom justice as a predictor of students' perceptions of empowerment and emotional response
}

\author{
Michelle L. Paulsel \\ West Virginia University
}

Follow this and additional works at: https://researchrepository.wvu.edu/etd

\section{Recommended Citation}

Paulsel, Michelle L., "Classroom justice as a predictor of students' perceptions of empowerment and emotional response" (2005). Graduate Theses, Dissertations, and Problem Reports. 2652.

https://researchrepository.wvu.edu/etd/2652

This Dissertation is protected by copyright and/or related rights. It has been brought to you by the The Research Repository @ WVU with permission from the rights-holder(s). You are free to use this Dissertation in any way that is permitted by the copyright and related rights legislation that applies to your use. For other uses you must obtain permission from the rights-holder(s) directly, unless additional rights are indicated by a Creative Commons license in the record and/ or on the work itself. This Dissertation has been accepted for inclusion in WVU Graduate Theses, Dissertations, and Problem Reports collection by an authorized administrator of The Research Repository @ WVU.

For more information, please contact researchrepository@mail.wvu.edu. 
Classroom Justice as a Predictor of Students' Perceptions of Empowerment and Emotional Response

\author{
Michelle L. Paulsel
}

\author{
Dissertation submitted to the \\ College of Human Resources and Education \\ at West Virginia University \\ in partial fulfillment of the requirements \\ for the degree of
}

\author{
Doctor of Education \\ in \\ Educational Psychology
}

\author{
Richard T. Walls, Ph. D., Chair \\ Floyd L. Stead, Ed. D. \\ Neal Shambaugh, Ph. D. \\ Rebecca M. Chory-Assad, Ph. D. \\ Matthew M. Martin, Ph. D.
}

Department of Advanced Educational Studies, Educational Psychology Program

\author{
Morgantown, West Virginia \\ 2005
}

Keywords: classroom justice, distributive justice, procedural justice, interactional justice, emotional response, learner empowerment

Copyright 2005 Michelle L. Paulsel 


\section{ABSTRACT \\ Classroom Justice as a Predictor of Students' Perceptions of Empowerment and Emotional Response}

Michelle L. Paulsel

One purpose of this dissertation was to examine the emotional response theory in the instructional context. A second purpose of this dissertation was to determine the predictive power of classroom justice. The effects of distributive, procedural, and interactional justice on students' emotional response and perceptions of empowerment were examined. Students $(N=$ 511) completed questionnaires about the class they had immediately before the class in which data were collected. Results indicated that classroom justice positively predicted students' emotional response and perceptions of empowerment. This dissertation also examined the relationships between students' emotional response and their perceptions of empowerment. Results indicated that each factor of emotional response was positively related to each factor of empowerment. The interaction of high/low pleasure and high/low arousal was analyzed in relation to student empowerment. However, no significant results were found for the interaction of pleasure and arousal. Implications and limitations of these findings in the instructional context were discussed. In addition, directions for future research were offered. 


\section{Dedication}

This dissertation is dedicated to Quentin Morris. Thank you for your love, support, and encouragement. 


\section{Acknowledgements}

I would like to thank Dr. Dick Walls, the chair of my dissertation committee. I enjoyed completing this dissertation due to his patience and thorough feedback. I also would like to thank

Dr. Rebecca Chory-Assad for inviting me to conduct research with her throughout my time at West Virginia University. I am a better researcher and team player because of her mentoring. Finally, I would like to thank the other members of my dissertation committee. Dr. Neal Shambaugh, Dr. Larry Stead, and Dr. Matt Martin provided excellent feedback and assistance while I wrote this dissertation. 
Table of Contents

Chapter $1 \quad$ REVIEW OF LITERATURE...........................................

Emotional Response Theory

Classroom Justice

Perceptions of Empowerment

Significance and Purpose of Study

Hypotheses and Research Questions

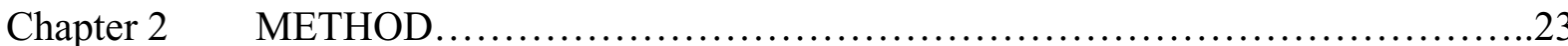

Participants

Procedure

Instrumentation

Data Analysis

Chapter 3 RESULTS.

Hypothesis One

Hypothesis Two

Research Question One

Research Question Two

Chapter 4 DISCUSSION .36

Findings and Implications for Hypotheses

Findings and Implications for Research Questions

Psychometric Properties of Instruments

Limitations of the Study

Directions for Future Research 


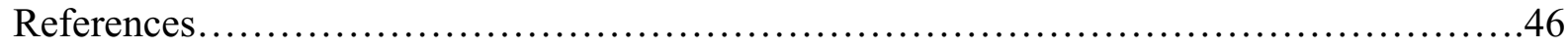

Appendix A: Classroom Justice Scales..............................................52

Appendix B: Emotional Response Scales........................................55

Appendix C: Learner Empowerment Scale..........................................56 


\section{List of Figures and Tables}

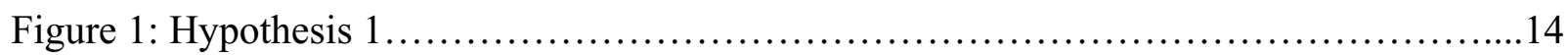

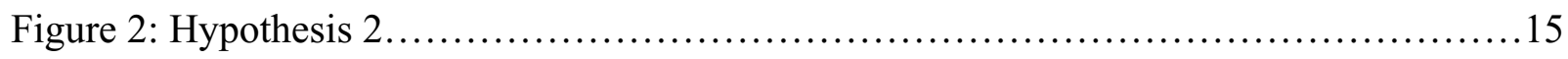

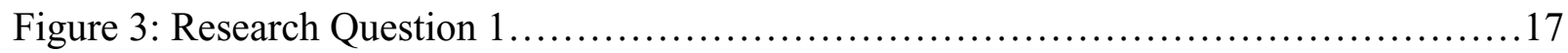

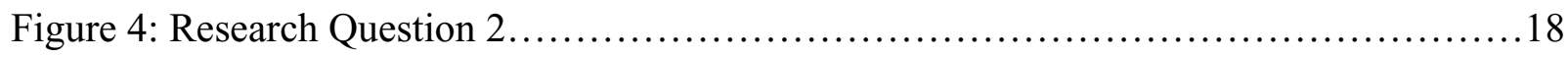

Table 1: Internal Consistency of Instruments.....................................20

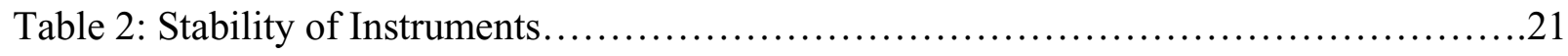

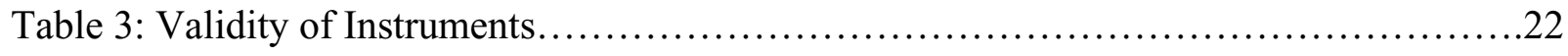

Table 4: Means and Standard Deviations for Each School...............................24

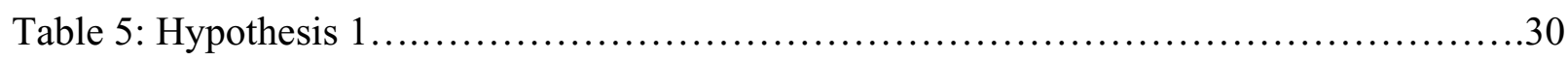

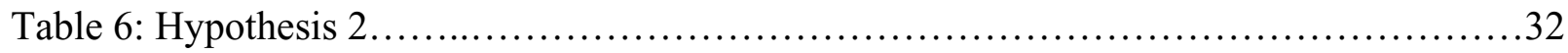

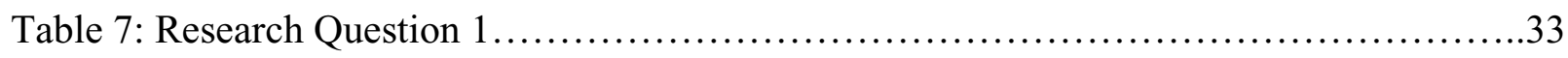

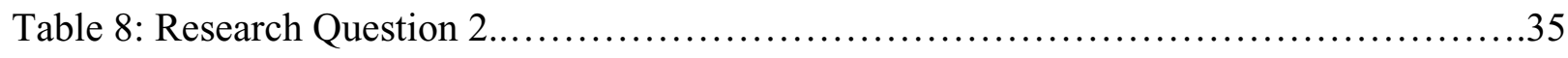




\section{Chapter 1}

\section{REVIEW OF LITERATURE}

Recent studies suggest the teacher-student relationship is an interpersonal one (Frymier \& Houser, 2000; Paulsel \& Chory-Assad, 2004c). This means that instructors and students must work together and negotiate to accomplish their individual goals in the classroom (Frymier \& Houser, 2000). While instructors might value effective teaching behaviors, student motivation, and learning, students sometimes differ in their expectations of instructors and the learning experience. For example, students believe that referential skills (presenting information clearly), ego supportive skills (helping students feel good about themselves), and conflict management skills (reaching solutions that satisfy both parties' needs) are among the most important for an instructor to possess (Frymier \& Houser, 2000). Additionally, students dislike instructors to embarrass them, use unjustified discipline and aggression, show inappropriate affection, or have unrealistic expectations (West, 1994). Examining students' perceptions of the teacher-student relationship as an interpersonal relationship is key to understanding their expectations of instructors and the learning experience.

The purpose of this dissertation was to continue examining the teacher-student relationship as an interpersonal one. To accomplish this goal, this study focused on three concepts important to the instructional setting: students' emotional response in the classroom, classroom justice, and students' perceptions of empowerment. When these concepts are implemented or invoked in a positive manner, students and instructors appear to benefit (ChoryAssad, 2002; Frymier, Houser, \& Shulman, 1996; Mottet \& Beebe, 2002).

The next section of this chapter offers a definition and detailed description of the emotional response theory, classroom justice, and students' perceptions of empowerment. Also, 
the significance and purpose of this dissertation are explained. The last section of the chapter poses hypotheses and research questions along with their rationale.

\section{Emotional Response Theory}

This study used the emotional response theory as a framework to examine the teacherstudent relationship. While the theory was not labeled until the 1970 s, a long line of research exists that examines emotional responses in reaction to stimuli (Mehrabian \& Russell, 1974). An emotion refers to "a feeling and its distinctive thoughts, psychological and biological states, and range of propensities to act" (Golman, 1995, p. 289). In his book, The Rhetoric, Aristotle was among the first scholars to recognize that emotions can affect individuals' judgments. He suggested that in order to understand emotions, people must try to determine (a) the mental state of the person experiencing the emotion, (b) who might be causing the emotion, and (c) the situational factors that might trigger the emotion (Aristotle, trans. 1984). In 1872, Darwin analyzed emotions in more detail by identifying specific emotions people experience such as anxiety, joy, anger, fear, and helplessness. In addition to his extensive identification of emotions, he explained how individuals express emotions through the use of facial and body movements (Darwin, 1998/1872). The initial investigations of emotions by Aristotle and Darwin provided a starting point for analyzing emotions in modern research.

To date, researchers view an individual's temperament as a precursor to emotions, moods, and emotional responses. That is, people experience varying degrees of emotional reactions depending on their personality traits of extroversion, neuroticism, and psychoticism (Fisher, 1997; Revelle, Anderson, \& Humphreys, 1987). When people experience emotions, they typically occur in response to particular events (Guerrero, Andersen, \& Trost, 1998). Scholars disagree on how many basic emotions exist. However, surprise, anger, disgust, fear, interest, 
sadness, and happiness are among the most commonly cited emotions (Guerrero et al., 1998;

Larsen, 1991). Emotions also are very brief and often last for only a few seconds. Once an individual feels an emotion, a mood emerges.

A mood is more muted than an emotion, but tends to last much longer (Goleman, 1995). It contains the feelings of the emotion experienced and a predisposition toward an emotional response (Fisher, 1997). To distinguish a mood from an emotion, Batson, Shaw, and Oleson (1992) stated, "whereas mood reflects a change in expectation about the general likelihood of positive or negative affect in the future, emotion reflects the existence of a specific goal or of perceived change in one's relation to a specific goal in the present" (p. 301). An emotional response is, in part, determined by temperament and also consists of the initial feeling of the emotion and the subsequent mood.

Emotional responses can be trait or state reactions to stimuli (Mehrabian \& Russell, 1974). Trait emotional responses are enduring experiences that are related to an individual's temperament and a relatively stable mood (Larsen, 1991). For example, people with neurotic introversion tend to have a high level of anxiety and apprehension regardless of the environmental triggers that may emerge in a situation (Beatty, McCroskey, \& Heisel, 1998). State emotional responses, however, are feelings that change from moment to moment given various stimuli in the environment. Mehrabian and Russell (1974) outlined the beginnings of an emotional response theory by claiming that people have both trait and state emotional reactions to stimuli. They identified three orthogonal emotional responses that people experience: pleasure, arousal, and dominance. Mehrabian (1980) suggested that all three emotional responses must be considered and are sufficient to assess a person's emotional reaction to stimuli. The 
emotional responses of pleasure, arousal, and dominance have varying magnitudes and directions.

Pleasure. The emotional response of pleasure ranges from extreme happiness and ecstasy to extreme pain or unhappiness. A person who has a pleasurable emotional response typically experiences greater liking for the stimuli (Mehrabian, 1981). For students, a pleasurable emotional response is related to increased liking for the course and instructor (Mottet \& Beebe, 2002; Mottet, Frymier, \& Beebe, in press). The pleasure dimension is often referred to as a person's feelings about the stimuli and references the valance of an emotion (Guerrero et al., 1998; Scherer, 1994).

Arousal. The emotional response of arousal ranges from feeling sleepy to experiencing frenzied excitement. It is defined by heightened mental awareness or increased physical activity (Mehrabian, 1980). For students, an aroused emotional response relates to increased perceptions of cognitive and affective learning (Beebe \& Mottet, 2002). The arousal dimension is often referred to as a person's physiological change when faced with stimuli (Guerrero et al., 1998; Scherer, 1994). This might include, for example, students who become excited and more motivated to learn when faced with a novel classroom activity.

Dominance. The emotional response of dominance is defined by perceptions of power and control and ranges from feelings of mastery to feelings of submissiveness. The dominance dimension often is referred to as action readiness and includes a person's increased or decreased desire to take action and engage in goal directed behavior (Lorr, 1997; Scherer, 1994). For students, the increased desire to take action relates to an increased likelihood of attending class, taking additional courses in related content areas, and taking another course taught by the same instructor that stimulated the emotional response. To explain this finding, Mottet and Beebe 
(2002) suggested that students who experience more feelings of dominance also have more feelings of empowerment.

Feelings indicated by pleasure, physiological change indicated by arousal, and action readinesses indicated by dominance make up three of the components that characterize emotions. While Mehrabian (1980) stated that these were the main emotional responses, a fourth component exists, which is a cognitive one that refers to how people interpret their emotional response to stimuli. This component influences perceptions, beliefs, and judgments people make about the stimuli (Scherer, 1994). Asking students to report their emotional response and the impact of that response is an example of how the cognitive component manifests itself in emotion research.

In addition to this parsimonious account of emotional responses, researchers have used the emotional response theory because of its explanatory power. For example, the theory provides an explanation for communication apprehension in the public speaking context (Biggers, 1987; Biggers \& Masterson, 1984) and emotional responses experienced when watching anxiety-producing television shows (Beebe \& Biggers, 1986). When faced with the stimuli of delivering a speech or watching a scary show, people tended to experience less pleasure and dominance and more arousal. Consequently, they became more apprehensive or anxious.

In the instructional context, emotional response theory provides a superior explanation for students' perceptions of teacher immediacy than the arousal-attention theory, student motivation theory, and learning theory (Mottet \& Beebe, 2002). When teachers were nonverbally immediate, students experienced more pleasure, arousal, and dominance. The positive emotional response related to more cognitive and affective learning. The explanatory power of emotional 
response theory makes it appealing to apply to the instructional context to explain how students' feelings of pleasure, arousal, and dominance might relate to their perceptions of classroom justice and empowerment.

\section{Classroom Justice}

Classroom justice is defined as "perceptions of fairness regarding outcomes or processes that occur in the instructional context" (Chory-Assad \& Paulsel, 2004b, p. 254). There are three types of classroom justice: distributive, procedural, and interactional. Distributive justice refers to perceptions that the outcomes of a given transaction are fair (Tata \& Bowes-Sperry, 1996). Students might perceive distributive justice based on the grades they receive on individual assignments or the overall course grade (Chory-Assad, 2002). Procedural justice refers to perceptions that the procedures used to arrive at outcomes are fair (Thibaut \& Walker, 1975). Students might perceive procedural justice based on policies and procedures outlined in the course syllabus or articulated in class that emphasize how the course is conducted, such as attendance and makeup policies, the grading scale used in the course, and scheduling of exams and written assignments (Chory-Assad, 2002). Interactional justice refers to fairness in the interpersonal treatment individuals receive from those who make decisions and if they are treated with respect (Bies \& Moag, 1986). Students might perceive interactional justice based on how well instructors treat them and understand their feelings, concerns, and needs (Chory-Assad \& Paulsel, 2004a).

A programmatic line of research considers the role of justice in the instructional context. Chory-Assad (2002) was among the first researchers to consider the impact of classroom justice on the teacher-student relationship. Results of this initial study suggested that, on the positive side, distributive and procedural justice were positively related to student motivation and 
affective learning. On the negative side, students reported that they would be more likely to use indirect interpersonal aggression against their instructors when they perceived that the instructors were not using procedural justice. Indirect interpersonal aggression includes behaviors that harm instructors without the students having face-to-face interactions with their instructors. Findings from this study suggest that students benefit from classroom justice and consider retaliation when they perceive injustice.

To further analyze the types of retaliation students might use in response to perceived injustice, a second study was conducted (Chory-Assad \& Paulsel, 2004b). Findings from this subsequent study suggested that in addition to indirect interpersonal aggression, students were more likely to engage in hostility when they perceived less procedural justice. They also were more likely to use student resistance strategies, which included behaviors like seeking revenge or being deceptive with instructors. Up to this point, only procedural and distributive justice were analyzed in the instructional context.

Chory-Assad and Paulsel (2004a) extended the line of research in a third study by focusing on interactional justice. They found that when teachers used the antisocial behavior alteration techniques of punishing students and making them feel guilty, students perceived less interactional justice. That is, students felt like they were treated with less respect when their instructors attempted to influence their behavior with negative strategies. Similar to the previous two studies in this line of research, this study found that students reported an increased likelihood of using of indirect interpersonal aggression against the instructor when they perceived less interactional justice.

The next two studies in this line of research continued to analyze students' negative responses to interactional injustice (Paulsel \& Chory-Assad, 2004a; 2004b). As with previous 
studies analyzing procedural and distributive justice, Paulsel and Chory-Assad (2004b) also confirmed that when instructors used antisocial behavior alteration techniques (BATs), students perceived less interactional justice. Specifically, students perceived the interpersonal treatment they received as unfair when their instructors used the following BATs: made threats of punishment, made students feel guilty, created a negative teacher-student relationship, appealed to their legitimate power as "the teacher" or a legitimate higher authority, or made students feel like they were indebted to the class. In a separate study, students reported that they would resist each of these antisocial BATs by using a variety of student resistance strategies (Paulsel \& Chory-Assad, 2004b; 2004c). The most commonly cited resistance strategies were to assign blame to the instructor, model the instructor's lack of affect for the course, and complain to a higher authority, such as a department chair or dean (Paulsel \& Chory-Assad, 2004c).

Results from these studies suggested that an instructor's use of power might relate to their students' perceptions of justice (Paulsel \& Chory-Assad, 2004a; 2004b). The next study in this line of research sought to determine the validity of this claim (Paulsel, Chory-Assad, \& Dunleavy, 2004). Results indicated that the use of coercive power (the power to punish students) negatively related to perceptions of procedural and interactional justice. Referent power (the power granted to the instructor because he/she is likable) positively related to interactional and procedural justice. Reward power (the power to reward students) was positively related to distributive and interactional justice. Legitimate power (the power granted to the teacher as part of the job title) and expert power (the power granted because of knowledge or competence) positively related to all three types of classroom justice. How instructors use the power granted by their students appears to positively and negatively relate to perceptions of classroom justice. 
The negative consequences for the teacher-student relationship appear to be evident from this line of research. Perceptions of less procedural, distributive, and interactional justice result in various forms of antisocial responses from students (Chory-Assad, 2002; Chory-Assad \& Paulsel, 2004a; 2004b; Paulsel \& Chory-Assad, 2004a). The positive aspects of classroom justice have received less empirical attention; however, several studies reveal how students benefit from classroom justice.

One finding suggested that students perceived credible instructors to be more just (ChoryAssad, 2005). Specifically, instructors who demonstrated competence, good character, and a caring demeanor were seen as more just. A second finding suggested that instructors who presented information clearly and gave constructive feedback, had students who understood the reasons behind the grades they received and viewed their instructors as using more procedural justice (Chesebro, Martin, \& Bulson, 2004). A third finding indicated that teacher confirmation positively related to procedural justice (Chesebro \& Bulson, 2004). Teacher confirmation occurred when instructors indicated that their students were valuable and significant individuals. Such behavior appears to facilitate positive perceptions of justice.

Limited information is known about the benefits of classroom justice on the teacherstudent relationship. This dissertation seeks to identify some positive outcomes of classroom justice by examining students' perceptions of justice in relation to their emotional response in the classroom and their perceptions of empowerment.

\section{Perceptions of Empowerment}

Empowerment is defined as "the humanistic process of adopting the values and practicing the behaviors of enlightened self-interest so that personal and organizational goals may be aligned in a way that promotes growth, learning, and fulfillment" (Luechauer \& Shulman, 1993, 
p. 13). In the organizational context, perceptions of empowerment result in employees feeling more effective (Conger \& Kanungo, 1988), motivated (Warr, Cook, \& Wall, 1979), and involved (Kanungo, 1982). Frymier et al. (1996) applied the construct of empowerment to the instructional context. They found that empowerment consists of three dimensions important to students: meaningfulness, impact, and competence.

Meaningfulness refers to how valuable students perceive a task according to their personal beliefs and standards. Impact refers to students' perceptions that they can make a difference in the classroom, such as influencing the teacher and other students or providing information in class discussions. Competence refers to students' feelings about their abilities and how capable they believe they are when completing classroom activities and tasks.

The three dimensions of empowerment relate to teacher and student behaviors. For example, teachers who were responsive tended to have students who felt more empowered (Burant, 1999). However, verbally aggressive teachers tended to have students who felt less empowered. Empowerment positively related to students' increased communication with their instructors outside of instructional time and students' state motivation (Knapp \& Martin, 2003). Students were also more interested in class when they felt empowered (Weber, Martin, \& Cayanus, in press; Weber \& Patterson, 2000). These findings suggest that empowerment is an important motivation-based variable that should be considered in relation to other teacher and student variables (Frymier et al., 1996).

While limited research examines perceptions of empowerment in the classroom, the construct appears to benefit students and their learning. Empowerment might be influenced by students' emotional responses and their perceptions of classroom justice. The significance of 
considering how these constructs might operate in relation to one another is offered in the next section of this chapter.

Significance and Purpose of Study

When students perceive injustice in the classroom, they might experience something called a neural hijacking. Goleman (1995) explained that a neural hijacking occurs when someone responds to an emotion before the neocortex or rational part of the brain has a chance to judge if the response is appropriate. A neural hijacking also is called an emotional explosion, which might be the culprit of extreme incidents of rage and anger directed toward instructors. For example, a sophomore at a high school in Coral Springs, Florida stabbed his physics teacher in the collarbone with a butcher knife after receiving an 80 on a quiz. The boy was a straight-A student and thought the grade would ruin his dreams of going to medical school at Harvard. The judge who heard the case found the student innocent and stated that it was a case of temporary insanity ("Warning," 1992). While this is an extreme emotional explosion to perceived injustice, numerous studies suggest that students are likely to have a negative emotional response and negatively react when they perceive injustice from their instructors.

When students perceived the course procedures as unfair, they reported an increased likelihood of engaging in revenge, deception, hostility, and aggression toward the instructor (Chory-Assad, 2002; Chory-Assad \& Paulsel, 2004b). Students were more likely to engage in indirect aggression when they perceived the quality of interpersonal treatment received from the instructor as unfair (Chory-Assad \& Paulsel, 2004a). The potential of these negative student behaviors escalating into dangerous acts makes classroom justice an important construct to analyze along with students' emotional responses to perceptions of fairness. 
As a positive aspect of the current study, educators might be able to understand how students benefit from fairness in the classroom. One possible benefit from using just practices might be a positive emotional response in students resulting in increased pleasure, arousal, and dominance. Such an emotional response is known to increase student motivation and learning (Mottet \& Beebe, 2002). Another benefit from using just practices might be that students feel more empowered in the classroom. They might find the content more meaningful, feel like they have an impact on the class, and feel more confident as learners. The potential benefits from studying classroom justice, emotional response, and empowerment suggest that these variables are important in the instructional context and are worthy of study. Hypotheses and Research Questions

Goleman (1995) proposed that there are two different memory systems: rational and emotional. The rational mind deals with working memory and learning ordinary facts. The emotional mind deals with emotional memory and learning feelings associated with facts. While numerous studies examine the role of cognitive learning in the classroom as part of the rational mind (Chesebro \& McCroskey, 2000), fewer studies examine students' emotional response to stimuli in the classroom as part of the emotional mind (Mottet \& Beebe, 2002; Mottet et al., in press).

When instructors use classroom justice, students appear to benefit (Chory-Assad, 2002). This is especially true for student motivation and affective learning. The teacher-student relationship also appears to benefit from classroom justice as students report a lower likelihood of resisting the instructor (Paulsel \& Chory-Assad, 2004a) and using less aggression and hostility (Chory-Assad, 2002; Chory-Assad \& Paulsel, 2004a, 2004b). The positive outcomes of classroom justice in previous studies suggest that they will positively predict an emotional 
response that is marked by more feelings of pleasure, arousal, and dominance. Classroom justice also is likely to positively predict students' perceptions of empowerment. Students are likely to find the content more meaningful, feel like they have more of an impact on the class, and feel more competent. In order to study the emotional mind in more detail and determine the predictive power of classroom justice, the following hypotheses are posed (see Figure 1 and Figure 2):

H1: Classroom justice positively predicts students' perceptions of pleasure, arousal, and/or dominance.

H2: Classroom justice positively predicts students' perceptions of meaningfulness, impact, and/or competence.

The relationship between students' emotional response and perceptions of empowerment remains unknown. Before emotional response theory can be used to explain perceptions of empowerment, a relationship between the dimensions of these two sets of variables needs to be determined. Mottet et al. (in press) stated that people pursue stimuli they like, prefer stimuli they have a positive emotional response for, and are influenced by the implicit messages of others. Based on their explanation of emotional response theory, students' emotional responses might be related to their perceptions of empowerment. That is, students who have a positive emotional response in the classroom might feel more empowered.

The conceptual definitions of emotional response and empowerment appear to overlap. First, pleasure experienced by how well a student is doing in class might relate to how meaningful a student finds the course content. Mehrabian (1981) provided a rationale for this claim by suggesting that more feelings of pleasure tend to produce more liking. Pleasure also might be related to students' perceptions of the impact they have on the class and their 
Figure 1

Hypothesis 1: Classroom justice positively predicts students’ perceptions of pleasure, arousal, and/or dominance (to be assessed with 3 multiple regression analyses).

Classroom Justice

Emotional Response
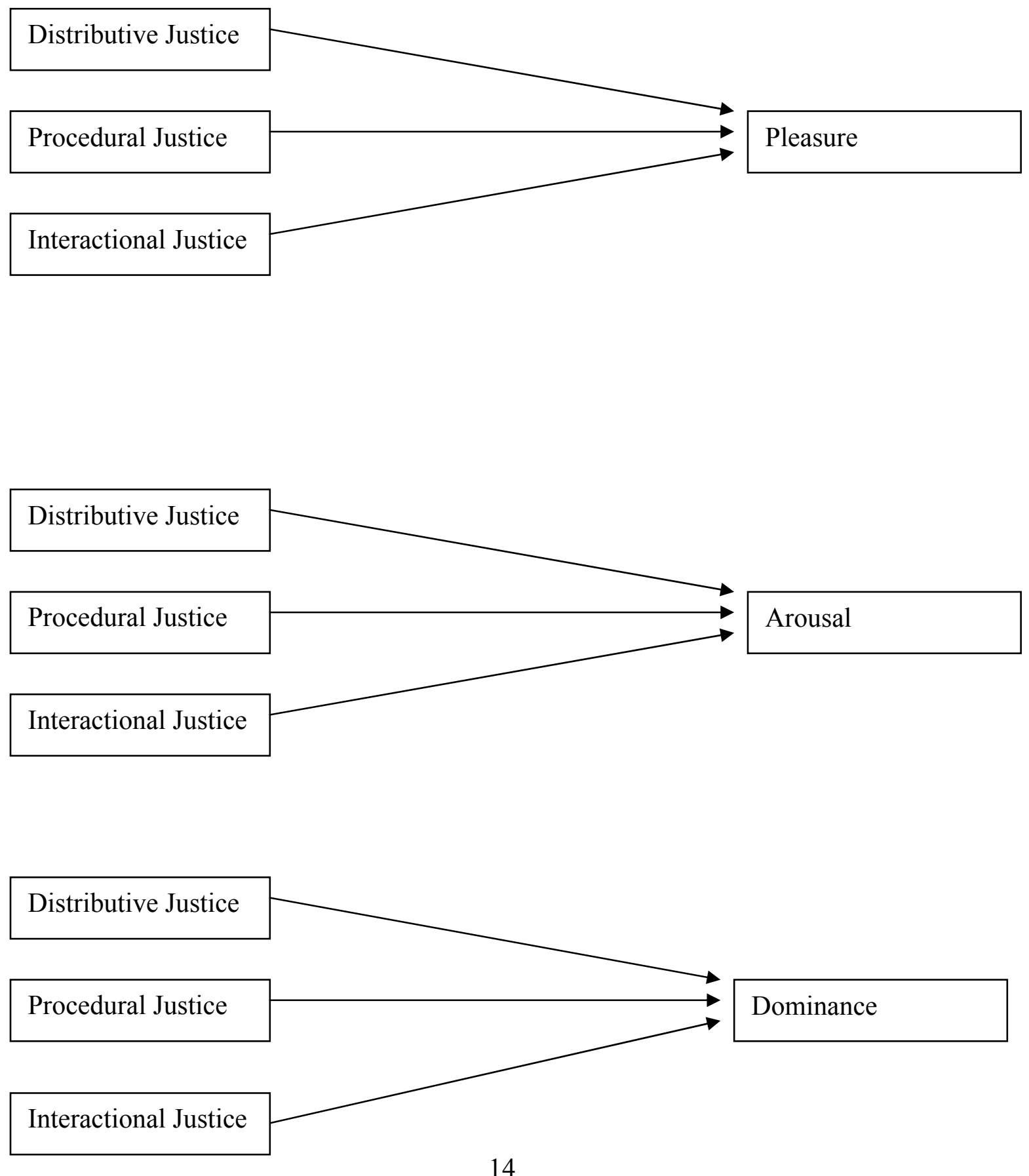
Figure 2

Hypothesis 2: Classroom justice positively predicts students’ perceptions of meaningfulness, impact, and/or competence (to be assessed with 3 multiple regression analyses).
Classroom Justice
Empowerment
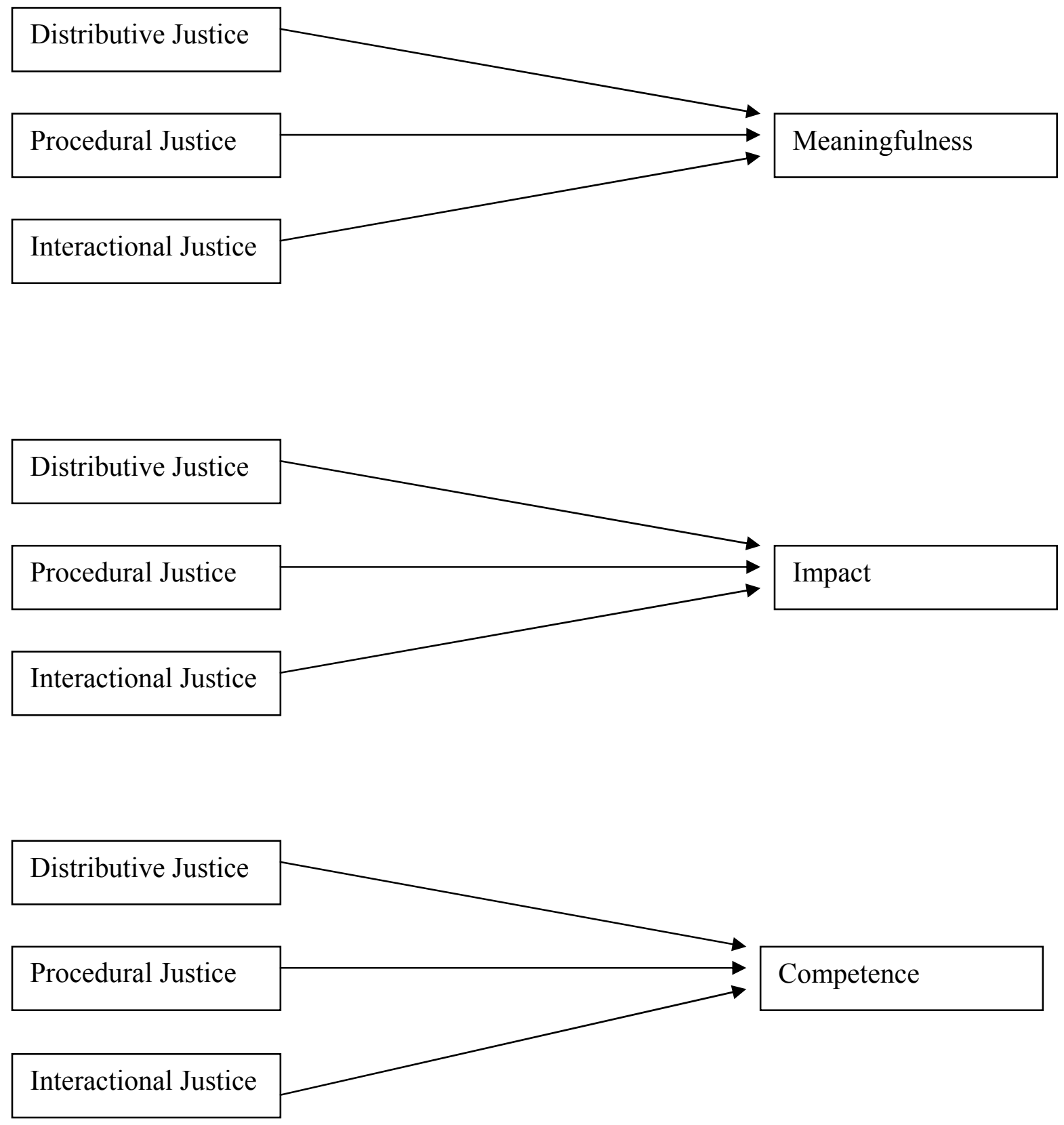
competence. Second, the sense of mobilization or energy that students experience with the emotional response of arousal might correspond with students' perceptions that they can make an impact in the classroom. This also might be true for students' perceptions of how meaningful the content is and their level of competence. Third, feelings of power and control that emerge from the emotional response of dominance might relate to students' perceptions of their competence in the classroom. Mottet and Beebe (2002) suggested that the emotion of dominance tends to result in greater feelings of empowerment and confidence. Dominance also might relate to students' perceptions that they have an impact on the class and find the content meaningful.

Even though emotional response theory asserts that people like stimuli they have positive emotions for and the conceptual definitions of the variables appear to overlap, the current study questions whether an emotional response coincides with students' perceptions of empowerment. Students might be conditioned to listen for content that will be assessed on exams or used after graduation. Consequently, they might not experience strong emotions in the classroom, especially in large lecture classes where students tend to be more passive and anonymous to the instructor. The specific relationships between the dimensions of emotional response and learner empowerment remain unknown and need to be determined. Therefore, the following research question was posed (see Figure 3):

RQ1: What is the nature of the relationship between students' emotional response and their perceptions of empowerment?

Guttman (1954) used the term circumplex to refer to a nonrestrictive correlation pattern that has a distinctive circular ordering. The circumplex model of emotions (see Figure 4) typically involves how variables fall in a circular pattern around the emotional responses of 
Figure 3

Research Question 1: What is the nature of the relationship between students' emotional response and their perceptions of empowerment (to be assessed with nine Pearson productmoment correlation tests)?

Emotional Response

Empowerment

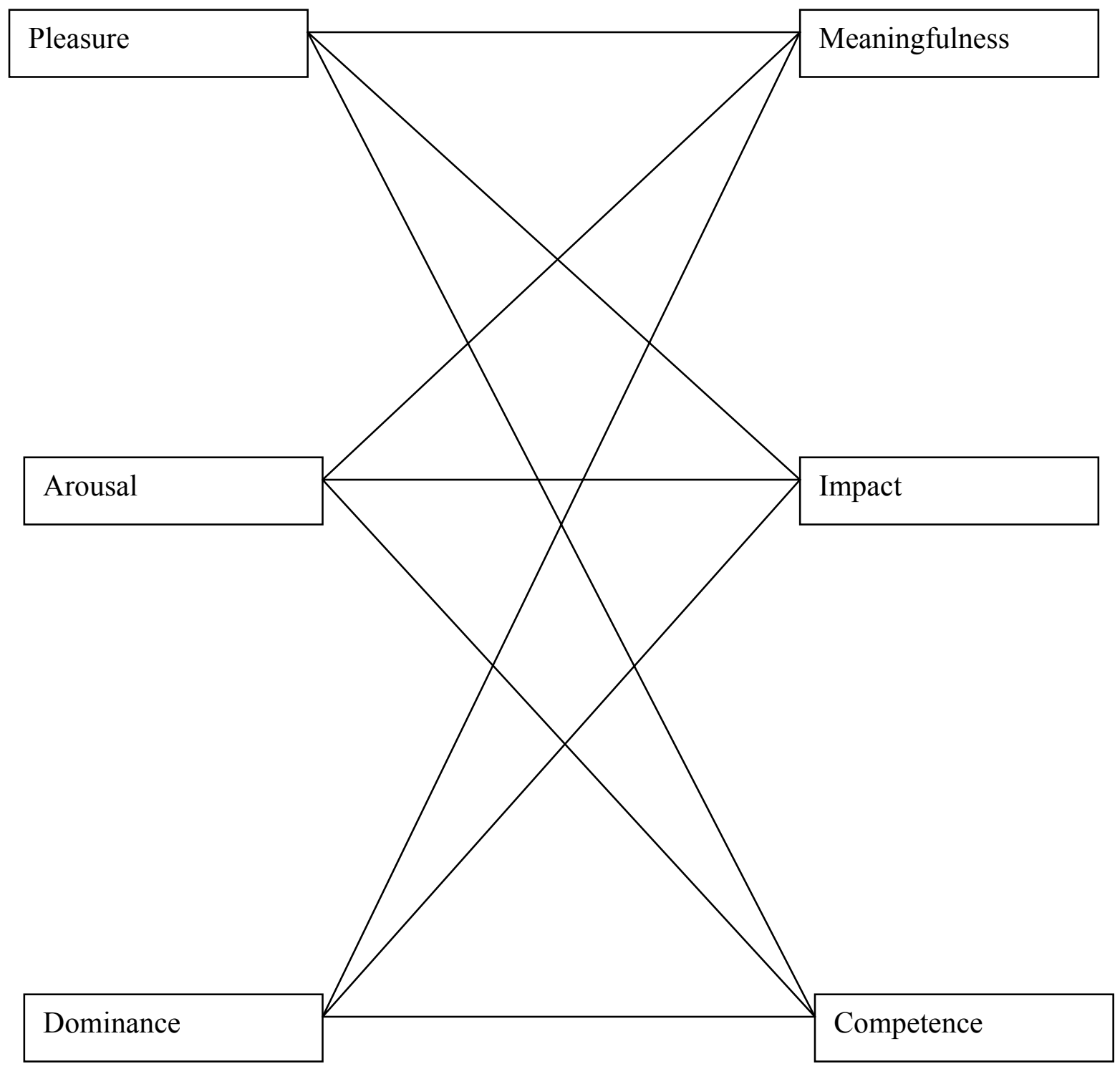


Figure 4

Research Question 2: How do students' perceptions of meaningfulness, impact, and competence fall on a circumplex model of emotions (to be assessed with 3 two-way analysis of variance (ANOVA) tests)?

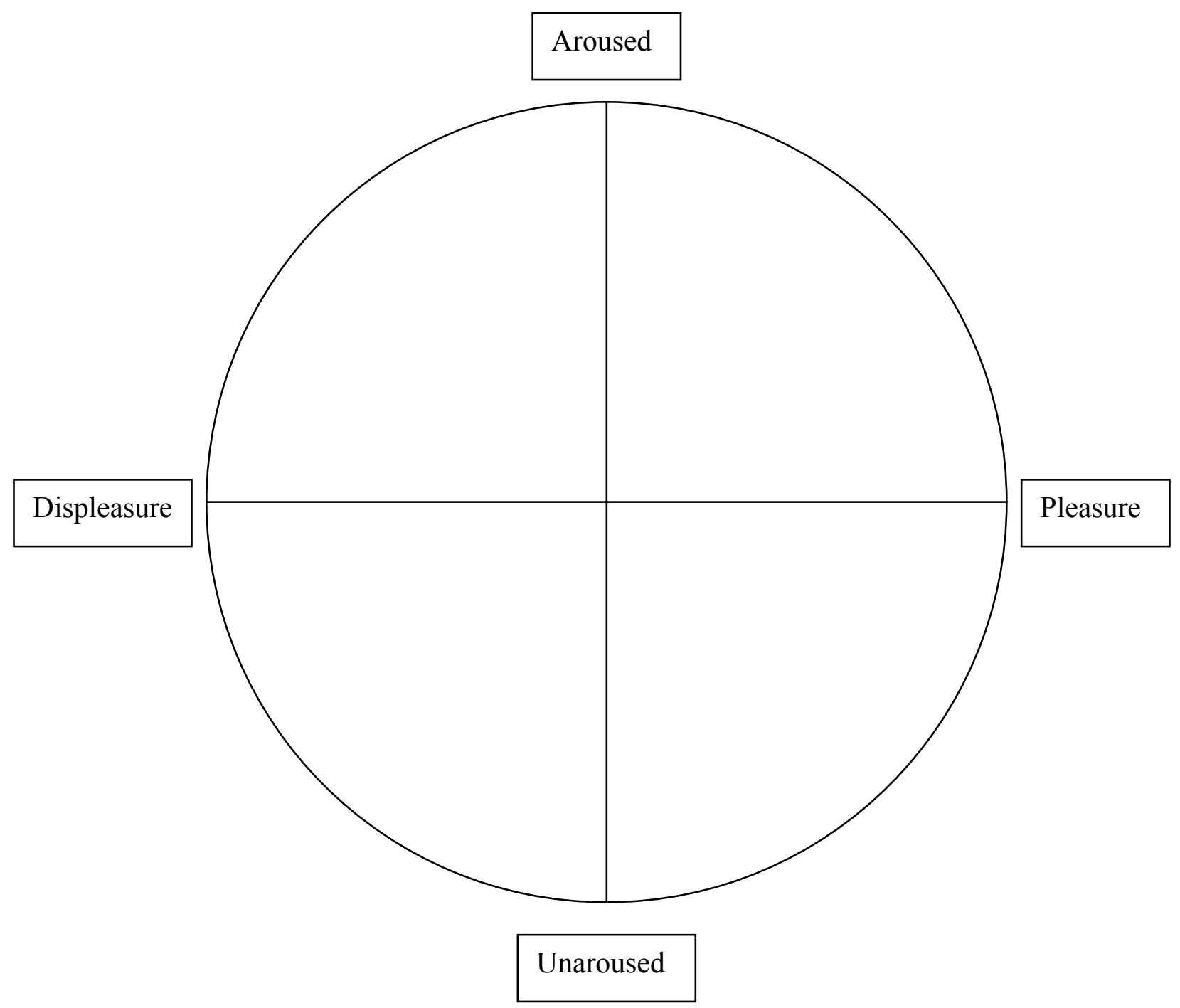


pleasure and arousal (Larsen, 1991; Larsen \& Diener, 1992). Analyzing data in this manner is beneficial to determine if the variables in question have equal communality with the two emotional responses in the circumplex (Gurtman, 1997). It is also beneficial to determine if the variables in question are likely or unlikely to be experienced together by students.

In the current study, meaningfulness, impact, and competence likely fall in a cluster or near each other around the circumplex since they are all types of the overarching construct of empowerment. However, how the variables interact with varying degrees of pleasure and arousal remains unknown. That is, the interaction effects of high and low pleasure with high and low arousal should be examined in a $2 \times 2$ design to better understand students' perceptions of empowerment. To determine how students' perceptions of empowerment fall around the emotions of pleasure and arousal, the following research question was asked:

RQ2: How do students' perceptions of meaningfulness, impact, and competence fall on a circumplex model of emotions?

The hypotheses and research questions posed in this section will address important reliability and validity issues for the instruments used to assess the constructs mentioned in this dissertation. Specifically, the reliability of each variable will be determined, the predictive validity of the instruments will be assessed, and construct validity of the instruments will be discussed. Analyzing the reliability and validity of the instruments will provide important insight into the usefulness of the instruments compared to past research (See Tables 1-3). 
Table 1

Internal Consistency of Instruments

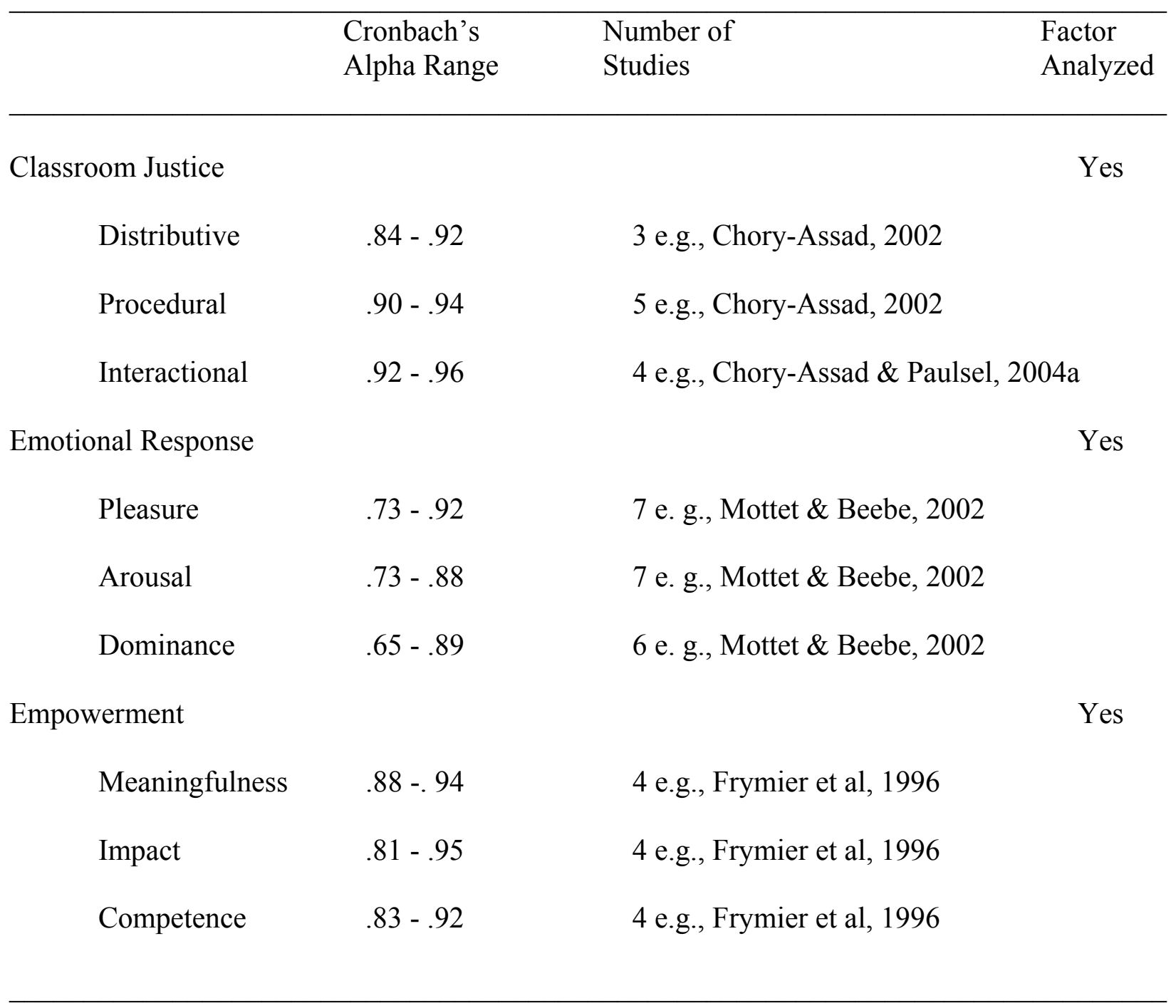


Table 2

Stability of Instruments

Test-Retest

Reliability

Classroom Justice No

Emotional Response No

Empowerment No 
Table 3

Validity of Instruments

$\begin{array}{ll}\text { Validity Examined } & \begin{array}{l}\text { Number of } \\ \text { and Examples }\end{array} \\ \text { Studies }\end{array}$

Concurrent Validity

Classroom Justice $\quad$ Yes $\quad$ e.g., Chory-Assad \& Paulsel, 2004b

Emotional Response No $\quad 0$

Empowerment Yes e.g., Weber \& Patterson, 2000

Predictive Validity

$\begin{array}{lcl}\text { Classroom Justice } & \text { Yes } & \text { e.g., Chory-Assad, } 2002 \\ \text { Emotional Response } & \text { Yes } & \text { e.g., Vinson \& Nutt, } 1992 \\ \text { Empowerment } & \text { Yes } & \text { e.g., Burant, 1999 }\end{array}$

Construct Validity

Classroom Justice $\quad$ Yes $\quad$ e.g., Chory-Assad \& Paulsel, 2004b 2

Emotional Response Yes e.g., Mottet \& Beebe, 2002

Empowerment $\quad$ Yes e.g., Frymier et al., 1996 


\section{Chapter 2}

\section{METHOD}

This chapter outlines the methodology used in the study to test the hypotheses and answer the research questions presented in the previous chapter. This chapter consists of four sections. The first section identifies characteristics about the participants. The second section of this chapter explains the administration of the questionnaire. The third section explains how the variables were operationalized. The last section of this chapter explains the procedures used to analyze the data.

\section{Participants}

Participants consisted of 511 (291 male, 220 female) undergraduate students enrolled in introductory level courses at three universities throughout the United States. Two of the universities were from the mid-Atlantic region and one university was from the Southern region of America (see Table 4). Data indicated that 113 (22.1\%) of the participants were 18 years old or younger, $339(66.3 \%)$ were between 19 and 21 years old, $50(9.8 \%)$ were between 22 and 25 years old, and nine (1.8\%) were 26 years old or older. Data also indicated that 162 participants were in their first year of college, 208 participants were in their second year, 85 participants were in their third year, 45 participants were in their fourth year, ten participants were in their fifth year or higher, and one participant's classification was unknown. Students were asked to identify their race on the questionnaire. Data indicated that 469 (91.8\%) were Caucasian, $20(3.9 \%)$ were African American, 11 (2.2\%) were Asian American, five (1.0\%) were Hispanic, and six (1.2\%) identified themselves as "other."

Approximately $33.5 \%$ of the participants were natural science and medical industry majors, $31.9 \%$ were social science majors, $14.7 \%$ were sports management and exercise 
Table 4

Means and Standard Deviations for Each School

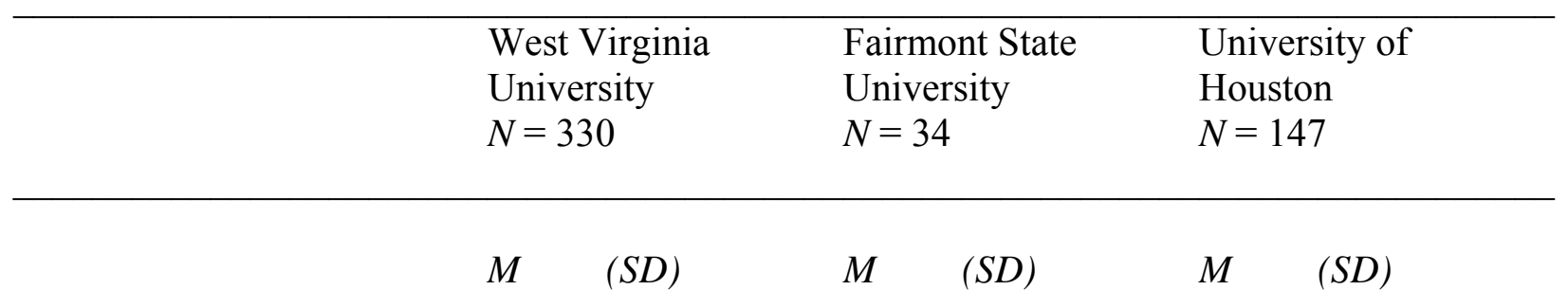

Emotional Response

$\begin{array}{lllllll}\text { Pleasure } & 26.08 & (7.19) & 27.97 & (7.04) & 25.94 & (8.12) \\ \text { Arousal } & 20.60 & (5.97) & 21.38 & (6.10) & 19.87 & (6.25) \\ \text { Dominance } & 24.93 & (5.59) & 26.33 & (6.03) & 24.38 & (6.99)\end{array}$

Classroom Justice

$\begin{array}{lllllll}\text { Distributive } & 52.19 & (11.31) & 54.67 & (10.72) & 52.25 & (11.37) \\ \text { Procedural } & 63.28 & (13.77) & 65.97 & (13.48) & 63.37 & (15.65) \\ \text { Interactional } & 35.04 & (7.29) & 35.62 & (7.14) & 34.98 & (7.99)\end{array}$

Empowerment

$\begin{array}{lllllll}\text { Meaningfulness } & 30.56 & (8.77) & 32.71 & (9.35) & 31.02 & (8.14) \\ \text { Impact } & 28.33 & (7.92) & 30.35 & (8.64) & 27.87 & (8.24) \\ \text { Competence } & 34.78 & (6.27) & 35.53 & (5.12) & 34.76 & (6.72)\end{array}$


physiology majors, $4.9 \%$ were education majors, $2.7 \%$ were humanities majors, and $12.3 \%$ were general studies majors or undecided. Approximately $40.1 \%$ of the courses on which participants reported were in the natural sciences, $28.0 \%$ were in the humanities, $26.2 \%$ were in the social sciences, and 5.7\% were in some other subject. These data reflect the course students had immediately before the course in which data were collected.

Most participants (39.9\%) reported on a class of 101 or more students, followed by 16 to 50 students $(38.9 \%), 51$ to 100 students $(12.5 \%)$, and 15 or fewer students $(8.0 \%)$. Three students $(0.6 \%)$ did not respond to the item about the size of the class. About $35.2 \%$ of the participants expected to receive an " $\mathrm{A}$ " in the course on which they reported, $40.7 \%$ expected to receive a "B," $20.0 \%$ expected to receive a " $\mathrm{C}$, , $2.3 \%$ expected to receive a " $\mathrm{D}$, ," $0.4 \%$ expected to fail the course, and $1.4 \%$ did not respond to the question.

\section{Procedure}

Participants voluntarily completed a questionnaire during the eleventh through the thirteenth weeks of the 15-week, Fall 2004 semester. Participants received a three-page document consisting of a cover letter requesting their assistance and a questionnaire approved by the Institutional Review Board. Using a method developed by Plax, Kearney, McCroskey, and Richmond (1986), participants completed the measures based on the course they were taking that met immediately before the course in which data collection occurred.

\section{Instrumentation}

The questionnaire included four instruments. The first instrument measured students' perceptions of classroom justice, including distributive, procedural, and interactional justice (see Appendix A). The second instrument measured students' emotional response, including their

feelings of pleasure, arousal, and dominance (see Appendix B). The third instrument measured 
students' empowerment, including their perceptions that the class was meaningful, they could make an impact in the class, and they felt competent (see Appendix C). The internal consistency, stability, and validity of the instruments can be seen in Tables 1-3 in the previous chapter. The last instrument asked participants to report demographic information about their sex, age, and ethnicity.

Classroom Justice. Perceptions of classroom distributive justice were assessed by ChoryAssad and Paulsel's (2004b) measure, which contains 14 items on which participants reported their perceptions of fairness about the grades they received or expected to receive in the given course. Participants' perceptions of classroom procedural justice were assessed by Chory-Assad and Paulsel's (2004b) measure, which contains 17 items on which participants evaluated the fairness of the instructor's policies and schedules. Participants evaluated the items on the distributive and procedural justice measures on a five-point Likert scale ( 1 = extremely unfair, 5 $=$ extremely fair). Higher scores represented perceptions of more justice.

Perceptions of classroom interactional justice were assessed by Chory-Assad and Paulsel's (2004a) Instructor Interactional Justice scale. This measure contains nine items on which participants report their perceptions of the given instructor's interpersonal treatment of students. Each item was preceded by the phrase, "The instructor of the class I am taking that meets immediately before the class I am in now..." Participants evaluated the items on the interactional justice measure on a 5-point Likert scale with responses ranging from strongly disagree to strongly agree. Higher scores represented perceptions of more interactional justice.

Emotional response. Students' emotional response was measured with an 18-item instrument developed by Mehrabian and Russell (1974) and adapted for the classroom context by Mottet and Beebe (2002). The instrument consists of three factors: pleasure, arousal, and 
dominance. Participants indicated their emotions on a seven-point scale by responding to bipolar words. Six sets of words were used to measure each factor. The pleasure factor included words such as joyful/miserable and comfortable/uncomfortable. The arousal factor included words such as jittery/dull and sleepy/wide awake. The dominance factor included words such as bold/meek and powerful/powerless.

Empowerment. Students' perceptions of empowerment were measured with the Learner Empowerment Instrument developed by Frymier et al. (1996). The instrument measures three factors of empowerment. The meaningfulness factor consists of 10 items that assess students' perceptions that the content is valuable and worthy of study, such as "the tasks required of me in the class are personally meaningful." The impact factor consists of 10 items that assess the importance of participating in class and performing well on class assignments, such as "My participation is important to the success of this class." The competence factor consists of nine items that assess students' perceptions of their confidence and abilities to do well in class, such as "I feel confident that I can adequately perform my duties."

Participants used a five-point, Likert-type response scale to indicate how often each item corresponded with their perceptions of the class. A score of zero indicated that the student "never" perceived the item. A score of four indicated that the student perceived the item "very often.”

Data Analysis

Alphas were set at .05 for all tests. Multiple regression analyses were conducted to address the first and second hypotheses. A series of Pearson product-moment correlation tests was conducted to answer the first research question. To answer the second research question, 
data were coded for high and low emotional responses for pleasure and arousal. Then, two-way analysis of variance (ANOVA) tests were conducted. 


\section{Chapter 3}

\section{RESULTS}

\section{Hypothesis One}

The first hypothesis predicted that students' perceptions of classroom justice would positively predict their perceptions of pleasure, arousal, and dominance. The alpha reliability coefficients and descriptive statistics for the classroom justice measures were $\alpha=.94(M=52.4$, $S D=11.3)$ for distributive justice, $\alpha=.95(M=63.5, S D=14.3)$ for procedural justice, and $\alpha=$ $.94(M=35.1, S D=7.5)$ for interactional justice. The alpha reliability coefficients and descriptive statistics for the emotional response measures were $\alpha=.88(M=26.1, S D=7.5)$ for pleasure, $\alpha=.73(M=20.4, S D=6.1)$ for arousal, and $\alpha=.86(M=24.9, S D=6.1)$ for dominance.

Results of multiple regression analyses indicated that students' perceptions of classroom justice positively predicted pleasure $(R=.64, F(3,444)=100.3, p<.05)$, arousal $(R=.29, F(3$, $453)=14.0, p<.05)$, and dominance $(R=.47, F(3,454)=43.3, p<.05)$. The first hypothesis was confirmed (see Table 5). Classroom justice explained $41 \%$ of the variance in the pleasure factor of emotional response with distributive, procedural, and interactional justice significantly

contributing to the model. Classroom justice explained $8 \%$ of the variance in the arousal factor of emotional response with only interactional justice significantly contributing to the model.

Classroom justice explained $22 \%$ of the variance in the dominance factor of emotional response with procedural and interactional justice significantly contributing to the model.

\section{Hypothesis Two}

The second hypothesis predicted that students' perceptions of classroom justice would positively predict their perceptions of meaningfulness, impact, and competence. In the current 
Table 5

Hypothesis 1: Classroom justice positively predicts students' perceptions of pleasure, arousal, and/or dominance

Multiple Regressions for Emotional Response

\begin{tabular}{|c|c|c|c|c|}
\hline & $\beta$ & $\mathrm{R}$ & $\mathrm{R}^{2}$ & $\mathrm{~F}$ \\
\hline Pleasure & & $.64 *$ & .41 & 100.3 \\
\hline Distributive & $.22 * *$ & & & \\
\hline Procedural & $.27 * *$ & & & \\
\hline Interactional & $.24 * *$ & & & \\
\hline Arousal & & $.29^{*}$ & .08 & 14.0 \\
\hline Distributive & .03 & & & \\
\hline Procedural & .13 & & & \\
\hline Interactional & $.17 * *$ & & & \\
\hline Dominance & & $.47 *$ & .22 & 43.3 \\
\hline Distributive & .07 & & & \\
\hline Procedural & $.26^{* *}$ & & & \\
\hline Interactional & $.21 * *$ & & & \\
\hline
\end{tabular}

Note: ${ }^{*} p<.05$ for the regression tests; $* *$ indicates significant contributors to the regression tests 
study, the alpha reliability coefficients and descriptive statistics for the empowerment measures were $\alpha=.90(M=30.8, S D=8.6)$ for meaningfulness, $\alpha=.89(M=28.3, S D=8.1)$ for impact, and $\alpha=.89(M=34.8, S D=6.3)$ for competence.

Results of multiple regression analyses indicate that students' perceptions of classroom justice positively predicted meaningfulness $(R=.55, F(3,460)=65.2, p<.05)$, impact $(R=.56$, $F(3,459)=67.7, p<.05)$, and competence $(R=.63, F(3,460)=97.8, p<.05)$. The second hypothesis was confirmed (see Table 6). Classroom justice explained 30\% of the variance in the meaningfulness factor of empowerment with procedural and interactional justice significantly contributing to the model. Classroom justice explained $30 \%$ of the variance in the impact factor of empowerment with procedural and interactional justice significantly contributing to the model. Classroom justice explained $39 \%$ of the variance in the competence factor of empowerment with distributive and procedural justice significantly contributing to the model.

\section{Research Question One}

The first research question asked about the nature of the relationship between students' emotional response and their perceptions of empowerment. Results of a series of Pearson product-moment correlation tests suggested that students' emotional response positively related to their perceptions of empowerment at a statistically significant level (see Table 7). That is,

pleasure, arousal, and dominance positively relate to meaningfulness, impact, and competence. 
Table 6

Hypothesis 2: Classroom justice positively predicts students' perceptions of meaningfulness, impact, and/or competence

Multiple Regressions for Empowerment

\begin{tabular}{|c|c|c|c|c|}
\hline & $\beta$ & $\mathrm{R}$ & $\mathrm{R}^{2}$ & $\mathrm{~F}$ \\
\hline Meaningfulness & & $.55^{*}$ & .30 & 65.2 \\
\hline Distributive & -.05 & & & \\
\hline Procedural & $.40 * *$ & & & \\
\hline Interactional & $.24 * *$ & & & \\
\hline Impact & & $.56^{*}$ & .30 & 67.7 \\
\hline Distributive & .04 & & & \\
\hline Procedural & $.19 * *$ & & & \\
\hline Interactional & $.39 * *$ & & & \\
\hline Competence & & $.63 *$ & .39 & 97.8 \\
\hline Distributive & $.37 * *$ & & & \\
\hline Procedural & $.26^{* *}$ & & & \\
\hline Interactional & .05 & & & \\
\hline
\end{tabular}

Note: ${ }^{*} p<.05$ for the regression tests; $* *$ indicates significant contributors to the regression tests 
Table 7

Research Question 1: What is the nature of the relationship between students' emotional response and their perceptions of empowerment?

Pearson Correlations between Emotional Response and Empowerment

\begin{tabular}{llll}
\hline & Pleasure & Arousal & Dominance \\
\hline Meaningfulness & .65 & .47 & .49 \\
Impact & .53 & .38 & .50 \\
Competence & .52 & .21 & .47 \\
\end{tabular}

* All results are significant at $p<.05$ 


\section{Research Question Two}

The second research question asked how students' perceptions empowerment fell on a circumplex model of emotions. Results of two-way analysis of variance (ANOVA) tests suggested that pleasure and arousal did not significantly interact to predict students' perceptions of meaningfulness $(p>.05)$, impact $(p>.05)$, and competence $(p>.05)$ (see Table 8$)$. Therefore, the results cannot be plotted on a circumplex model of emotions. 
Table 8

Research Question 2: How do students' perceptions of meaningfulness, impact, and competence fall on a circumplex model of emotions?

Results for Analysis of Variance Tests

\begin{tabular}{|c|c|c|c|}
\hline Source & $\mathrm{df}$ & MS & $\mathrm{F}$ \\
\hline \multicolumn{4}{|c|}{ Dependent Variable: Meaningfulness } \\
\hline Pleasure & 1 & 2016.2 & $67.9^{*}$ \\
\hline Arousal & 1 & 2.3 & 0.1 \\
\hline Pleasure x Arousal & 1 & 38.1 & 1.3 \\
\hline Error & 69 & 29.7 & \\
\hline \multicolumn{4}{|l|}{ Dependent Variable: Impact } \\
\hline Pleasure & 1 & 1197.8 & $26.4^{*}$ \\
\hline Arousal & 1 & 4.7 & 0.1 \\
\hline Pleasure x Arousal & 1 & 25.2 & 0.6 \\
\hline Error & 68 & 45.4 & \\
\hline \multicolumn{4}{|c|}{ Dependent Variable: Competence } \\
\hline Pleasure & 1 & 994.3 & $22.4 *$ \\
\hline Arousal & 1 & 109.1 & 2.5 \\
\hline Pleasure x Arousal & 1 & 2.6 & 0.1 \\
\hline Error & 69 & 44.4 & \\
\hline
\end{tabular}




\section{Chapter 4}

\section{DISCUSSION}

There were two main purposes for this dissertation. One purpose was to examine the emotional response theory in the instructional context. The second purpose was to extend the line of research examining classroom justice by analyzing its predictive power. To accomplish these two purposes, two hypotheses and two research questions were presented and analyzed. The hypotheses predicted the effects of distributive, procedural, and interactional justice on students' emotional response and perceptions of empowerment. The research questions asked about the nature of the relationship between students' emotional response and perceptions of empowerment. This chapter discusses the findings for each hypothesis and research question, identifies limitations, and offers directions for future research.

\section{Findings and Implications for Hypotheses}

Two hypotheses were presented to determine the predictive power of classroom justice. The first hypothesis stated that classroom justice would positively predict an emotional response in students, consisting of pleasure, arousal, and/or dominance. This hypothesis was confirmed for all three factors of emotional response. When students perceive their instructors as engaging in behaviors, such as grading fairly, using just policies and procedures, and treating students with respect, they find the course more pleasurable, are more psychologically aroused in class, and feel dominant in their roles as students.

In order to understand emotions in others, Aristotle (trans. 1984) suggested that people must try to determine (a) the mental state of the person experiencing the emotion, (b) who might be causing the emotion, and (c) the situational factors that might trigger the emotion. His suggestions seem relevant to the findings for the first research hypothesis. While the tenets he 
outlined dealt with emotions that others feel, this study dealt with emotional responses. It is important to note that emotions underlie an emotional response (Guerrero et al., 1998).

Therefore, instructors should make an effort to determine the emotions underpinning students' emotional responses in the classroom.

To apply Aristotle's first tenet, instructors should take time to reflect on their observations of students' emotions. Research by Darwin (1998/1872) suggested that people can and do express their emotions through their facial and/or body movements. Instructors should try to determine if their students are happy, sad, anxious, or experiencing other emotions by trying to interpret their nonverbal behaviors in the classroom. Results for the first research hypothesis indicate that students experience more pleasure, arousal, and dominance when instructors use classroom justice. Since pleasure indicates people's feelings, arousal indicates physiological change, and dominance indicates action readiness, it is likely that positive emotions accompany the emotional response influenced by classroom justice.

To apply Aristotle's second tenet, instructors should try to determine the cause of their students' emotions. While the current study did not seek to establish a causal relationship between classroom justice and students' emotional responses, the results suggest that students' perceptions of their instructors' behaviors appear to influence their emotional responses. One might be tempted to identify classroom justice as "causing" students" emotional responses. However, research examining the attribution theory in the instructional context suggests that such a claim should not be made without asking the students who or what caused their emotions (Kelsey, Kearney, Plax, Allen, \& Ritter, 2004). Future research should determine if students attribute their perceptions of pleasure, arousal, and dominance to classroom justice. The results 
of the first hypothesis simply suggest that the three types of classroom justice positively predict pleasure, arousal, and dominance.

Aristotle's third tenet suggested that situational factors might trigger an emotion. The effects of distributive, procedural, and interactional justice appear to be situational factors influencing students' emotional responses. In addition, students' underlying temperament, emotions experienced prior to class, or moods need to be considered. Research indicates that these three elements make up an emotional response and should not be ignored (Goleman, 1995; Guerrero et al., 1998). When interpreting the findings for the first hypothesis, one should not rule out the possibility that intervening variables might exist. Other variables might influence students' emotional response, such as instructors' credibility (Chory-Assad, 2005), clarity in teaching (Chesebro et al., 2004), and confirming messages given to students (Chesebro \& Bulson, 2004). Future research should attempt to identify additional situational factors that might explain students' emotional responses.

The second hypothesis predicted that classroom justice would positively predict students' perceptions of meaningfulness, impact, and/or competence. This hypothesis was confirmed for all three factors of empowerment. That is, when teachers were just, students found the content to be more meaningful, they felt like they could have more of an impact on the class, and they felt more competent in the class.

The results from this hypothesis might be used to improve the teacher-student relationship. More specifically, instructors might be able to use classroom justice as a way of relating to students and helping them feel empowered. When instructors develop thorough rubrics to aid in fair grading, consciously try to make the course objectives achievable, and treat students equally, they might be building a stronger rapport with students in addition to helping 
students feel empowered. Frymier et al. (1996) adds support to this claim by explaining the benefits of student empowerment in terms of increased state motivation, increased self-esteem, viewing the content as more relevant, and viewing the instructor as more verbally and nonverbally immediate. All of these benefits might help students relate, not only to the course, but to the instructor as well.

\section{Findings and Implications for Research Questions}

Two research questions were asked in this dissertation. The first research question inquired about the nature of the relationship between students' emotional response and their perceptions of empowerment. Positive relationships were found between each emotional response variable and each student empowerment variable. That is pleasure, arousal, and dominance all were related positively to meaningfulness, impact, and competence.

In addition to the conceptual definitions of emotional response and empowerment overlapping, the factors that make up the constructs also overlap. First, Mehrabian (1981) indicated that more feelings of pleasure tend to produce more liking. This appears to be a possible explanation for the results pertaining to the pleasure dimension of emotional response. Pleasure positively related to liking for the course as measured through students' perceptions of empowerment. Second, the sense of mobilization or energy that students experience with the arousal dimension of emotional response corresponded with students' perceptions that (a) the course is meaningful, (b) they can make an impact in the classroom, and (c) they are competent in completing the required tasks in the course. Third, feelings of power and control that emerge from the dominance dimension of emotional response relate to students' perceptions of empowerment. Courses invoking perceptions of dominance in students might give students confidence to see the course as empowering. Mottet and Beebe (2002) appear to be correct with 
their assertion that that the emotion of dominance tends to result in greater feelings of empowerment and confidence.

The second research question asked how the three factors of empowerment fell on a circumplex model of emotions. Pleasure (high and low) and arousal (high and low) did not significantly interact to predict meaningfulness, impact, or competence. Therefore, the factors of student empowerment could not be plotted on a circumplex.

While results from the first research question revealed that pleasure and arousal were each significantly related to meaningfulness, impact, and competence, the variables did not interact in the second research question to result in increased perceptions of empowerment. This is not to say that pleasure and arousal do not independently predict student empowerment. For example, pleasure produced significant main effects for each of the empowerment factors. Results for the second research question simply indicate that the interaction of high/low pleasure and high/low arousal do not significantly predict student empowerment.

\section{Psychometric Properties of Instruments}

Internal consistency. The instruments maintained their internal consistency in the current study. That is, the Cronbach's alpha reliability estimates were acceptable and consistent with reliability estimates from previous studies. While the reliability estimate for the emotional response factor of arousal was acceptable, it was at the low end of the range of reliability estimates for previous studies. One might question if the bipolar words/phrases in the arousal instrument invoked the same response from the students responding to the items. For example, students might have responded differently to the items of stimulated/relaxed and frenzied/sluggish. In addition, the inter-item reliability estimates for the emotional response 
factor of arousal ranged from .38 to .59 . This suggests that the items had low to moderate correlations with each other.

Construct validity. One also should question the construct validity of the arousal factor and other factors of emotional response. Since the emotional response instrument was modified from its original format for the instructional context (Mottet \& Beebe, 2002), more modifications might be needed to ensure that the instrument measures the core concepts of pleasure, arousal, and dominance that it was intended to measure. Data from the current study and other studies (e.g. Mottet \& Beebe, 2002) suggest that pleasure, arousal, and dominance are less predictive of and associated with communication variables than in studies that use more reliable emotional response measures. Alternative measures of emotional response should be considered in future research to further examine the construct validity.

Predictive validity. This study analyzed the predictive validity of the classroom justice and students' emotional response. For classroom justice, the interaction of procedural, interactional, and distributive justice positively predicted students' emotional response and perceptions of empowerment. These findings suggest that the classroom justice instruments do have predictive validity. For emotional response, this study only examined the interaction effects of pleasure and arousal. The interaction effects yielded did not have a significant effect on students' empowerment. Therefore, this study did not establish predictive validity for the emotional response factors of pleasure or arousal.

Concurrent validity. This study analyzed the nature of the relationship between students' emotional response and their perceptions of empowerment. In doing so, the concurrent validity of the scales that make up the constructs was examined. The correlations ranged from .21 to 65 . These results suggest that the low to moderate correlations between the variables establish 
concurrent validity for the scales that make up the emotional response and empowerment instruments. One would not expect the correlations to be much higher. Extremely high correlations would suggest that the different scales were measuring the same construct. Future research could further analyze the concurrent validity of the instruments by conducting a canonical correlation. Such a test would reveal how much overlap exists between the instruments.

\section{Limitations of the Study}

The results of this dissertation are only generalizable to an undergraduate student population. Additionally, only students from three universities were examined. The students were a convenient sample. Therefore, the results might not be representative of the larger American college student population. Caution should be used when applying the results of this study to various college students.

This study examined students' perceptions of their instructors' behavior. Actual classroom justice was not examined. There might be a significant difference between students' perceptions and instructors' actual behavior. Therefore, one should not equate the two.

This study examined students' state emotional responses, which are momentary feelings that tend to fade shortly after exposure to stimuli. Students were asked to think about the class they had immediately before the course in which data were collected. Too much time might have lapsed between the stimuli and when the data were collected, especially when data were collected in morning classes. Students might have referenced a class they had the pervious day and been unsuccessful in accurately recalling their state emotions. Russell and Steiger (1982) claimed that state emotions can effectively be measured after a time lapse because participants can recall their emotional responses. However, Beebe and Biggers (1986) suggested that 
researchers minimize the time between the introduction of the stimuli and participants' selfreport of their emotions. This strategy improved the accuracy of participants' responses. In the current study, students' emotional responses might have faded. This remains a limitation of the study.

A final limitation of this dissertation involves the mortality of potential participants from the classes they did not like. Data were collected from the eleventh to the thirteenth weeks of the semester. It is likely that students who perceived injustice, a lack of emotional response, and/or few feelings of empowerment dropped the disliked course by the time data were collected. If a significant number of students dropped the classes they did not like, then the sample used in this study might not be representative. To overcome this limitation, future research should replicate this study at an earlier point in the semester.

\section{Directions for Future Research}

Mottet et al. (in press) suggested that students' emotional response needed to be measured with increased validity and reliability. Future studies should examine similar constructs to students' emotional response that might be more accurate and reliable measurements. For example, Christophel (1990) developed the student motivation scale that contains several of the same items as the arousal dimension of the emotional response instrument used in the current study, such as excited/not excited and aroused/not aroused. Christophel's student motivation instrument might be more related to students' perceptions of empowerment, than the emotional response instrument used in this study. In a preliminary study, meaningfulness, competence, and impact all were correlated positively with student motivation (Knapp \& Martin, 2003). Future research should examine the extent to which student motivation and emotional response measure the same state reaction in students. 
Future research should examine the causal relationships between students' emotional responses, perceptions of classroom justice, and empowerment. Emotional response theory serves an explanatory function to analyze the affect students experience for their courses. A more controlled experiment, however, might be conducted to determine if classroom justice causes students' emotional response or perceptions of empowerment.

In addition, researchers should determine the influence of demographic variables on the variables investigated in this dissertation. Variables like participants' age, sex, and race might serve as intervening variables. Future research might, for example, examine differences in elementary, middle, and high school student populations to determine significant differences due to participants' ages.

\section{Conclusion}

The emotional response theory served as a framework for this dissertation. Reflecting on the theory in relation to the findings of this study provides important insights into its usefulness. First, the emotional response theory appears to have explanatory power. Results from this study suggest that the theory provides a logical explanation for students' emotions in the classroom. That is, when teachers are just, students experience an emotional response consisting of more feelings of pleasure, arousal, and dominance.

Second, the emotional response theory is parsimonious. Reducing an emotional response to three key elements (pleasure, arousal, and dominance) allows researchers to assess multiple aspects of the construct in a simple way. This is especially true in the classroom. The three factors of emotional response appear to play a significant role in the teacher-student relationship in this study and students' learning in a study conducted by Mottet and Beebe (2002). 
Finally, the emotional response theory is heuristically provocative. In other words, there are ample directions for future research that stem from the theory. The theory also applies to a variety of contexts other than the instructional setting, such as the public speaking context (Biggers, 1987; Biggers \& Masterson, 1984) and viewing television programs (Beebe \& Biggers, 1986). The theory serves as a useful framework in this study and should be useful in future research. 


\section{References}

Aristotle. (1984). The rhetoric (W. R. Roberts, Trans.). New York: McGraw-Hill. (Unknown original publication date)

Batson, C. D., Shaw, L. L., \& Oleson, K. C. (1992). Differentiating affect, mood, and emotion: Toward functionally based conceptual distinctions. In M. S. Clark (Ed.), Emotion: Review of personality and social psychology (pp. 294-326). Newbury Park, CA: Sage.

Beatty, M. J., McCroskey, J. C., \& Heisel, A. D. (1998). Communication apprehension as temperamental expression: A communibiological paradigm. Communication Monographs, 65, 197-219.

Beebe, S. A., \& Biggers, T. (1986). Trait emotion and emotional response. Communication Research Reports, 3, 47-52.

Bies, R. J., \& Moag, J. S. (1986). Interactional justice: Communication criteria of fairness. Research on Negotiation in Organizations, 1, 43-55.

Biggers, T. (1987). Trait emotion and communication apprehension. Communication Research Reports, 4, 20-25.

Biggers, T., \& Masterson, J. T. (1984). Communication apprehension as a trait: An emotional defense of a concept. Communication Monographs, 51, 381-390.

Burant, P. A. (1999). Students' perceptions of teachers' communication and its effects on students’ learning. Unpublished doctoral dissertation, West Virginia University, Morgantown, WV.

Chesebro, J. L, \& Bulson, A. (2004, April). The relationship between teacher confirmation and students perceptions of procedural justice. Paper presented at the annual meeting of the Eastern Communication Association, Pittsburgh, PA. 
Chesebro, J. L., Matin, M. M., Bulson, A. (2004, April). Further examining the nature and benefits of clear teaching: The relationships between teacher clarity, feedback to students, and student perceptions of fairness. Paper presented at the annual meeting of the Eastern Communication Association, Boston, MA.

Chesebro, J. L., \& McCroskey, J. C. (2000). The relationship between students' reports of learning and their actual recall of lecture material. Communication Education, 49, 297301.

Chory-Assad, R. M. (2002). Classroom justice: Perceptions of fairness as a predictor of student motivation, learning, and aggression. Communication Quarterly, 50, 58-77.

Chory-Assad, R. M. (2005). Enhancing student perceptions of fairness: The relationship between instructor credibility and classroom justice. Manuscript submitted for publication.

Chory-Assad, R. M., \& Paulsel, M. L. (2004a). Antisocial classroom communication: Instructor influence and interactional justice as predictors of student aggression. Communication Quarterly, 52, 98-114.

Chory-Assad, R. M., \& Paulsel, M. L. (2004b). Classroom justice: Student aggression and resistance as reactions to perceived unfairness. Communication Education, 53, 253-273.

Christophel, D. M. (1990). The relationship among teacher immediacy behaviors, student motivation, and learning. Communication Education, 39, 323-340.

Conger, J., \& Kanungo, R. (1988). The empowerment process: Integrating theory and practice. Academy of Management Review, 13, 471-482.

Darwin, C. (1998). The expression of the emotions in man and animal (P. Ekman, Trans.). New York: Oxford University Press. (Original work published 1872) 
Fisher, G. A. (1997). Theoretical and methodological elaborations of the circumplex model of personality and emotions. In R. Plutchik \& H. R. Conte (Eds.), Circumplex models of personality and emotions (pp. 245-269). Washington, DC: American Psychological Association.

Frymier, A. B., \& Houser, M. L. (2000). The teacher-student relationship as an interpersonal relationship. Communication Education, 49, 207-219.

Frymier, A. B., Shulman, G. M., \& Houser, M. (1996). The development of a learner empowerment measure. Communication Education, 45, 181-199.

Goleman, D. (1995). Emotional intelligence. New York: Bantam Books.

Guerrero, L. K., Andersen, P. A., \& Trost, M. R. (1998). Communication and emotion: Basic concepts and approaches. In P. A. Andersen \& L. K. Guerrero (Eds.), Handbook of communication and emotion: Research, theory, applications, and contexts (pp. 3-27). New York: Academic Press.

Gurtman, M. B. (1997). Studying personality traits: The circular way. In R. Plutchik \& H. R. Conte (Eds.), Circumplex models of personality and emotions (pp. 81-102). Washington, DC: American Psychological Association.

Guttman, L. (1954). A new approach to factor analysis: The radix. In P. F. Lazarsfeld (Ed.), Mathematical thinking in the social sciences (pp. 258-348). Glencoe, IL: Free Press.

Kanungo, R. (1982). Work alienation. New York: Praeger.

Kelsey, D. M., Kearney, P., Plax, T. G., Allen, T. H., \& Ritter, K. J. (2004). College students' attributions of teacher misbehaviors. Communication Education, 53, 40-55.

Knapp, J. L., \& Martin, M. M. (2003, November). The relationship between out-of-class 
communication, student interest, and student motivation. Paper presented at the annual meeting of the National Communication Association, Miami, FL.

Larsen, R. J. (1991). Emotion. In V. J. Derlega, B. A. Winstead, \& W. H. Jones (Eds.), Personality: Contemporary theory and research (pp. 407-432). Chicago: Nelson-Hall.

Larsen, R. J., \& Diener, E. (1992). Promises and problems with the circumplex model of emotion. In M. S. Clark (Eds.), Emotion: Review of personality and social psychology (pp. 25-59). Newbury Park, CA: Sage.

Lorr, M. (1997). The circumplex model applied to interpersonal behavior, affect, and psychotic syndromes. In R. Plutchik \& H. R. Conte (Eds.), Circumplex models of personality and emotions (pp. 47-56). Washington, DC: American Psychological Association.

Luechauer, D., \& Shulman, G. M. (1993). Empowerment at work: Separating folklore from fact. At work: Stories of tomorrow's workplace, 2, 13-14.

Mehrabian, A. (1980). Basic dimensions for a general psychological theory: Implications for personality, social, environmental and developmental studies. Cambridge, MA: Oelgeschlager, Gunn, \& Hain.

Mehrabian, A. (1981). Silent messages: Implicit communication of emotions and attitudes. Belmont, CA: Wadsworth.

Mehrabian, A., \& Russell, J. A. (1974). The basic emotional impact of environments. Perceptual and Motor Skills, 38, 283-301.

Mottet, T. P., \& Beebe, S. A. (2002). Relationships between teacher nonverbal immediacy, student emotional response, and perceived student learning. Communication Research Reports, 19, 77-88.

Mottet, T. P., Frymier, A. B., \& Beebe, S. A. (in press). Theorizing about instructional 
communication. In T. P. Mottet, V. P. Richmond, \& J. C. McCroskey (Eds.), Handbook of instructional communication: Rhetorical and relational perspectives (Chapter 13). Boston: Allyn and Bacon.

Paulsel, M. L., \& Chory-Assad, R. M. (2004a). Classroom justice: Perceptions of interactional justice as a predictor of student resistance. Paper presented at the annual meeting of the Central States Communication Association, Cleveland, $\mathrm{OH}$.

Paulsel, M. L., \& Chory-Assad, R. M. (2004b). The effects of antisocial behavior alteration techniques on student resistance and perceptions of justice. Paper presented at the annual meeting of the Eastern Communication Association, Boston, MA.

Paulsel, M. L., \& Chory-Assad, R. M. (2004c). The relationships among instructors' antisocial behavior alteration techniques and student resistance. Communication Reports, 17, 103112.

Paulsel, M. L., Chory-Assad, R. M., Dunleavy, K. N. (2004). Student perceptions of instructor power as a predictor of classroom justice. Manuscript submitted for publication.

Plax, T. G., Kearney, P., McCroskey, J. C., \& Richmond, V. P. (1986). Power in the classroom VI: Verbal control strategies, nonverbal immediacy and affective learning. Communication Education, 35, 43-55.

Revelle, W., Anderson, K. J., \& Humphreys, M. S. (1987). Empirical tests and theoretical extensions of arousal-based theories of personality. In J. Strelau \& H. J. Eysenck (Eds.), Personality dimensions and arousal (pp.17-36). New York: Plenum.

Russell, J. A., \& Steiger, J. A. (1982). The structure in persons implicit taxonomy of emotions. Journal of Research in Personality, 16, 447-469.

Scherer, K. R. (1994). Affect bursts. In S. H. M. Van Goozen, N. E. Van de Poll, \& J. A. 
Sergeant (Eds.), Emotions: Essays on emotion theory (pp. 161-193). Hillsdale, NJ: Erlbaum.

Tata, J., \& Bowes-Sperry, L. (1996). Emphasis on distributive, procedural, and interactional justice: Differential perceptions of men and women. Psychological Reports, 79, 13271330.

Thibaut, J., \& Walker, L. (1975). Procedural justice: A psychological analysis. Hillsdale, NJ: Erlbaum.

Vinson, L. R., \& Nutt, L. (1992). Implicit communication theory and learning: Understanding the causal nature of the process which produces the relationships between immediacy, emotional response, and learning. Paper presented at the annual meeting of the International Communication Association, Miami, FL.

War, P., Cook, J., \& Wall, T. (1979). Scales for the measurement of some work attitudes and aspects of psychological well-being. Journal of Occupational Psychology, 52, 129-148.

Warning by a valedictorian who faced prison. (1992, June 23). The New York Times, p. A1.

Weber, K., Martin, M. M., \& Cayanus, J. L. (in press). Why students communicate with their instructors: A multi-study reexamination of student interest. Communication Quarterly.

Weber, K., \& Patterson, B. R. (2000). Student interest, empowerment and motivation. Communication Research Reports, 17, 22-29.

West, R. (1994). Teacher-student communication: A descriptive typology of students interpersonal experiences with teachers. Communication Reports, 7, 109-118. 


\section{Appendix A}

\section{Classroom Justice Scales}

\section{Distributive Justice}

Your grade on the last exam compared to...

1. other students' grades on the exam

2. the grade you expected to receive on the exam

3. the grade you deserved to received on the exam

4. the effort you put in to studying for the exam

5. the grade(s) you received on other exams in this course

6. the grade most other students at this university would have received on the exam The grade you will probably receive in this course compared to...

7. the grades other students in the course will probably receive

8. the grade you expected to receive in this course at the beginning of the semester

9. the grade you feel you deserve to receive in this course

10. the effort you put in to this course

11. the grade(s) you've received in similar courses

12. the grade most other students at this university would receive in this course

The following items were assessed using a 5-point scale from extremely unfair to extremely fair.

13. Your grade on the last exam

14. The grade you will probably receive in this course 


\section{Procedural Justice}

1. The missed work make-up polices

2. The course attendance policies

3. The instructor's ways of grading exams, etc.

4. The grading scale for the course

5. The course's schedule of topics

6. How the instructor conducts class discussions

7. The way the instructor calls on students in class

8. The way the instructor conducts class

9. The course syllabus

10. The scheduling of exams

11. The instructor's expectations of students

12. The types of questions on exams

13. The amount of work required to get a good grade in the course

14. The number of questions on exams

15. The level of difficulty of the course content

16. The amount of time you need to put into this course to receive a good grade

17. The scheduling of homework and other written assignments 
Participants rated the fairness of the items listed below on a 5-point Likert-type scale with responses ranging from strongly disagree to strongly agree.

\section{Interactional Justice}

The instructor of the class I am taking that meets immediately before the class I am in now ...

1. treats students with dignity.

2. communicates with students in a respectful manner.

3. is sensitive to students' feelings.

4. listens to students' concerns.

5. understands students' needs.

6. considers students' viewpoints.

7. is able to suppress his/her personal biases in dealing with students.

8. treats students with kindness.

9. shows concern for students' rights. 
Appendix B

Emotional Response Scales

Items for Pleasure

1. Happy/Unhappy

2. Hopeful/Not hopeful

3. Joyful/Miserable

4. Comfortable/Uncomfortable

5. Pleased/Annoyed

6. Satisfied/Unsatisfied

Items for Arousal

1. Excited/Calm

2. Jittery/Dull

3. Aroused/Unaroused

4. Stimulated/Relaxed

5. Frenzied/Sluggish

6. Wide awake/Sleepy

Items for Dominance

1. Bold/Meek

2. Assertive/Not assertive

3. Dominant/Submissive

4. Powerful/Powerless

5. Domineering/Helpless

6. Decisive/Indecisive 
Appendix C

Learner Empowerment Scale

Items for Meaningfulness

1. The tasks required of me in this class are personally meaningful.

2. I look forward to going to this class.

3. This class is exciting.

4. This class is boring.*

5. This class is interesting.

6. The tasks required of me in this class are valuable to me.

7. The information in this class is useful.

8. This course will help me achieve my future goals.*

9. The tasks required in this course are a waste of my time.*

10. This course is not important to me.*

\section{Items for Impact}

1. I have the power to make a difference in how things are done in this class.

2. My participation is important to the success of this class.

3. I can make an impact on the way things are run in this class.

4. I have the opportunity to contribute to the learning of others in this class.

5. I cannot influence what happens in this class.

6. I have the power to create a supportive learning environment in this class.

7. My contribution to this class makes no difference.*

8. I make a difference in the learning that goes on in this class.

9. I can influence the instructor.

10. I feel appreciated in this class.

\section{Items for Competence}

1. I feel confident that I can adequately perform my duties.

2. I feel intimidated by what is required of me in this class.*

3. I possess the necessary skills to perform successfully in class.

4. I feel unable to do the work in this class.*

5. I believe that I am capable of achieving my goals in this class.

6. I have faith in my ability to do well in this class.

7. I have the qualifications to succeed in this class.

8. I lack confidence in my ability to perform the tasks in this class.*

9. I feel very competent in this class.

* Items are reverse coded 


\section{Curriculum Vita}

\section{Michelle L. Paulsel}

Michelle L. Paulsel was born in Houston, Texas, on June 23, 1978, the daughter of Dr.

John and Mary Paulsel. After completing her high school work at Saint Agnes Academy in Houston, Texas in 1997, she entered Texas State University at San Marcos. She received a Bachelor of Arts degree in Communication Studies from that university in May of 2000 and a Master's degree in Communication Studies in May of 2002. While earning a Master's degree, she worked as a graduate teaching assistant. She earned a Doctor of Education in Educational Psychology from West Virginia University in May of 2005. She also worked as a teaching assistant for the Department of Communication Studies at the university. 